\title{
Haloterrigena hispanica sp. nov., an extremely halophilic archaeon from Fuente de Piedra, southern Spain
}

\author{
Ida Romano, ${ }^{1}$ Annarita Poli, ${ }^{1}$ Ilaria Finore, ${ }^{1}$ F. Javier Huertas, ${ }^{2}$ \\ Agata Gambacorta, ${ }^{1}$ Salvatore Pelliccione, ${ }^{1}$ Giancarlo Nicolaus, ${ }^{3}$ \\ Licia Lama ${ }^{1}$ and Barbara Nicolaus ${ }^{1}$ \\ ${ }^{1}$ Istituto di Chimica Biomolecolare, Comprensorio ex Olivetti, via Campi Flegrei 34, \\ 80078 Pozzuoli, Napoli, Italy \\ ${ }^{2}$ CSIC, Estacion Experimental del Zaidin, Department of Earth Sciences and Environmental \\ Chemistry, Profesor Albareda 1, 18008 Granada, Spain \\ ${ }^{3}$ Istituto di Ricerche di Biologia Molecolare Angeletti IRBM, Pomezia, Roma, Italy
}

Correspondence

Barbara Nicolaus bnicolaus@icmib.na.cnr.it
Halophilic Archaea belonging to the order Halobacteriales are found in large numbers in the crystallizer ponds of solar salterns worldwide (Kamekura \& Dyall-Smith, 1995; Oren et al., 1997; Grant, 2004; Fendrihan et al., 2006). Several saline and hypersaline environments in Spain have been studied and many halophiles have been isolated from them. A few studies have described halophilic bacteria from the Fuente de Piedra saline lake in the province of Malaga, southern Spain (Martinez-Canovas et al., 2004; MartinezCheca et al., 2005; Mata et al., 2006), but no extremely halophilic archaea have been described from this lake.

\footnotetext{
Abbreviations: PG, phosphatidylglycerol; PGP-Me, phosphatidylglycerol phosphate methyl ester; PHB, poly- $\beta$-hydroxybutyric acid; S-DGD, mannose-6-sulfate(1-2)-glucose glycerol diether; $S_{2}$-DGD, mannose2,6-disulfate(1-2)-glucose glycerol diether.

The GenBank/EMBL/DDBJ accession number for the $16 \mathrm{~S}$ rRNA gene sequence of strain $F 1^{\top}$ is $A M 285297$.

A thin-layer chromatogram of total polar lipids and a table giving ${ }^{13} \mathrm{C}$ NMR assignments for polar lipids from strain $\mathrm{FP}^{\top}$ and related species are available with the online version of this paper.
}

In the present study, a novel member of the genus Haloterrigena is proposed on the basis of conventional physiological, biochemical and chemical characteristics and through phylogenetic analysis based on 16S rRNA gene sequences and DNA-DNA hybridization results. At the time of writing, the genus Haloterrigena comprises five species of extremely halophilic archaea, Haloterrigena turkmenica (Ventosa et al., 1999), Haloterrigena thermotolerans (Montalvo-Rodriguez et al., 2000), Haloterrigena saccharevitans (Xu et al., 2005a), Haloterrigena longa and Haloterrigena limicola (Cui et al., 2006). Owing to taxonomic problems arising within the genera Haloterrigena and Natrinema (Montalvo-Rodriguez et al., 2000; Xin et al., 2000; Tindall, 2003; Xu et al., 2005b; Wright, 2006; Castillo et al., 2006), a combination of other morphological and chemotaxonomic characters such as lipid analyses have been used to distinguish between species of these two genera.

Strain $\mathrm{FP}^{\mathrm{T}}$ was isolated from samples collected during summer 2005 from Fuente de Piedra saline lake, Malaga province, southern Spain $\left(37^{\circ} 6^{\prime} \mathrm{N} 4^{\circ} 44^{\prime} \mathrm{W}\right)$. 
Strain $\mathrm{FP}^{\mathrm{T}}$ was isolated from a saltern crystallizer pond by the dilution-plating technique. This strain represented the predominant organism in the enrichment and was the only colony-forming organism at the highest dilutions. Enrichment medium (medium 1; DSM 372) contained the following components (per litre): $5.0 \mathrm{~g}$ yeast extract (Oxoid), $5.0 \mathrm{~g}$ Casamino acids (Oxoid), $3.0 \mathrm{~g}$ trisodium citrate (Applichem), $2.0 \mathrm{~g} \mathrm{KCl}$ (Applichem), $20 \mathrm{~g}$ $\mathrm{MgSO}_{4} .7 \mathrm{H}_{2} \mathrm{O}$ (Carlo Erba), $200 \mathrm{~g} \mathrm{NaCl}$ (Applichem), $0.36 \mu \mathrm{g} \mathrm{MnCl}_{2} .4 \mathrm{H}_{2} \mathrm{O}$ (J. T. Baker) and $0.05 \mathrm{~g} \mathrm{FeSO}_{4} .7 \mathrm{H}_{2} \mathrm{O}$ (Carlo Erba). The pH of medium 1 was 7.0. Growth on single carbon sources (medium 2) was tested on liquid media containing (per litre) $200 \mathrm{~g} \mathrm{NaCl}$ (Applichem), $2.0 \mathrm{~g}$ $\mathrm{KCl}$ (Applichem), $1 \mathrm{~g} \mathrm{MgSO}_{4} .7 \mathrm{H}_{2} \mathrm{O}$ (Carlo Erba), $16.4 \mathrm{~g}$ $\mathrm{MgCl}_{2} \cdot 6 \mathrm{H}_{2} \mathrm{O}$ (Riedel-de Haën), $0.2 \mathrm{~g} \mathrm{NaHCO}_{3}$ (J. T. Baker), $2.29 \mathrm{~g} \mathrm{CaCl}_{2} .2 \mathrm{H}_{2} \mathrm{O}$ (J. T. Baker), $152 \mathrm{mg} \mathrm{NH}_{4} \mathrm{Cl}$ (Applichem), $33 \mathrm{mg} \mathrm{K} \mathrm{HPO}_{4}$ (Applichem), $0.26 \mathrm{mg} \mathrm{FeCl} \cdot 4 \mathrm{H}_{2} \mathrm{O}$ (J. T. Baker) and $10.0 \mathrm{~g}$ of the test compound. Solid media were prepared by the addition of $1.8 \%(\mathrm{w} / \mathrm{v})$ agar.

Haloterrigena turkmenica JCM $9191^{\mathrm{T}}$, Haloterrigena thermotolerans DSM $11552^{\mathrm{T}}$, Haloterrigena saccharevitans JCM $12889^{\mathrm{T}}$, Haloterrigena limicola JCM $13563^{\mathrm{T}}$ and Natrinema pellirubrum JCM $10476^{\mathrm{T}}$ (McGenity et al., 1998), obtained from the Deutsche Sammlung von Mikroorganismen und Zellkulturen, Braunschweig, Germany (DSMZ) and from the Japan Collection of Microorganisms (JCM), were grown in the media suggested by the culture collections (DSMZ medium no. 372 for Htg. turkmenica and Htg. thermotolerans; JCM medium no. 168 for Htg. saccharevitans, Htg. limicola and N. pellirubrum). Haloferax mediterranei CCM $3361^{\mathrm{T}}$ was grown as described by Lanzotti et al. (1988).

Cell morphology was determined by phase-contrast microscopy (Zeiss). Colony morphology was analysed on solid medium via a stereomicroscope (M8; Leica). Tolerance to $\mathrm{NaCl}$ and $\mathrm{MgSO}_{4}$ and growth at various temperatures and $\mathrm{pH}$ were tested in medium 1 . All growth tests were performed at the optimal growth temperature $\left(50^{\circ} \mathrm{C}\right)$ for 3 days. Sensitivity of the strain to antibiotics was tested by using medium 1 with agar $(1.8 \%$, w/v) and Sensi-discs (6 mm; Oxoid) (Romano et al., 1993). Phenotypic tests were performed according to the proposed minimal standards for the description of novel taxa of the order Halobacteriales (Oren et al., 1997). Gelatin hydrolysis was determined as described by Oren et al. (2002). Casein hydrolysis and oxidase, tyrosinase, aminopeptidase (Bactident-Merck) and catalase activities were tested in medium 1 as described by Oren et al. (1997). For nitrate reduction, medium 1 plus $0.1 \%(\mathrm{w} / \mathrm{v}) \mathrm{KNO}_{3}$ was employed. Hydrolysis of hippurate was tested in medium 1 plus hippurate $(1 \%, \mathrm{w} / \mathrm{v}$ ) (Poli et al., 2006). For the indole test, the novel strain was grown at $\mathrm{pH} 7.0$ in medium 1. Gram-staining was performed according to Dussault (1955). The $\mathrm{KOH}$ test was performed according to Halebian et al. (1981). Hydrolysis of $N^{\prime}$ benzoyl-arginine- $p$-nitroaniline (BAPNA) stereoisomers was tested as described by Oren \& Galinski (1994). Intracellular solutes and poly-hydroxybutyric acid ( $\mathrm{PHB}$ ) were extracted according to Motta et al. (2004) and Sykes (1971), respectively. Cell mass for quinone and lipid analyses was obtained from cultures of test strains grown under their optimal growth conditions for $24 \mathrm{~h}$. Lipid analysis, lipid hydrolysis and identification of core lipids were performed as reported by Nicolaus et al. (2001). Quinones were analysed by LC/MS on a reversed-phase column by Electron Impact MS (EI/MS) and $\mathrm{H}^{1}$ NMR spectra. Phospholipids and glycolipids were separated by TLC on silica gel plates $\left(10 \times 10 \mathrm{~cm} ; 10 \times 25 \mathrm{~cm} ; 0.25 \mathrm{~mm}, \mathrm{~F}_{254}\right.$; Merck $)$ and were analysed according to Nicolaus et al. (2001). Complex lipids of Hfx. mediterranei CCM $3361^{\mathrm{T}}$ were used as reference (Lanzotti et al., 1988).

The DNA G + C content was determined by the method of Tamaoka \& Komagata (1984) and the values given are the mean of three independent analyses of the same DNA sample. DNA was hydrolysed and the resultant nucleotides were analysed by HPLC. The DNA was isolated as described by Poli et al. (2006).

The 16S rRNA gene sequence was determined by direct sequencing of the PCR product. Genomic DNA extraction, amplification of the 16S rRNA gene and purification of the PCR products were carried out as described by Reed et al. (2006) with the primers $5^{\prime}$-CTGGTTGATCCTGCCAG-3' and $5^{\prime}$-ACGGCTACCTTGTTACGACTT-3'. Purified PCR products were sequenced by the DSMZ with the ABI PRISM Dye Terminator Cycle Sequencing Ready Reaction kit (Applied Biosystems) according to the manufacturer's recommendations. Sequence reactions were electrophoresed by using the Applied Biosystems 373A DNA sequencer.

The sequence of the novel strain was compared with closely related sequences of reference organisms from the FASTA network service. Sequence data were aligned with the CLUSTAL W 1.8 program (Chenna et al., 2003). Phylogenetic analysis was performed by using the PHYLIP package, version 3.6 (Felsenstein, 2004) and with the neighbour-joining method within the MEGA3 program package (Kumar et al., 2004). DNA-DNA hybridizations were performed at $48.5^{\circ} \mathrm{C}$ according to Ezaki et al. (1989) and the levels of DNA-DNA relatedness were calculated according to Goris et al. (1998). Hybridizations were carried out between strain $\mathrm{FP}^{\mathrm{T}}$ and related species (Htg. thermotolerans DSM $11552^{\mathrm{T}}$, Htg. saccharevitans JCM $12889^{\mathrm{T}}$ and Htg. limicola JCM $13563^{\mathrm{T}}$ ).

Cells of strain $\mathrm{FP} 1^{\mathrm{T}}$ were coccoid, Gram-negative and able to grow over a restricted range of salinities $(2.2-4.0 \mathrm{M} \mathrm{NaCl})$. Colonies on agar medium were light red-pigmented. Strain $\mathrm{FP} 1^{\mathrm{T}}$ did not require magnesium for growth and was unable to assimilate sugars (glucose, sucrose or maltose). Detailed results of morphological analyses, antibiotic sensitivity tests and biochemical tests for strain $\mathrm{FP}^{\mathrm{T}}$ are given in the species description below.

In a phylogenetic tree based on 16S rRNA gene sequences, strain $\mathrm{FP}^{\mathrm{T}}$ clustered with recognized species of the genus Haloterrigena (Fig. 1). 16S rRNA gene sequence similarities 


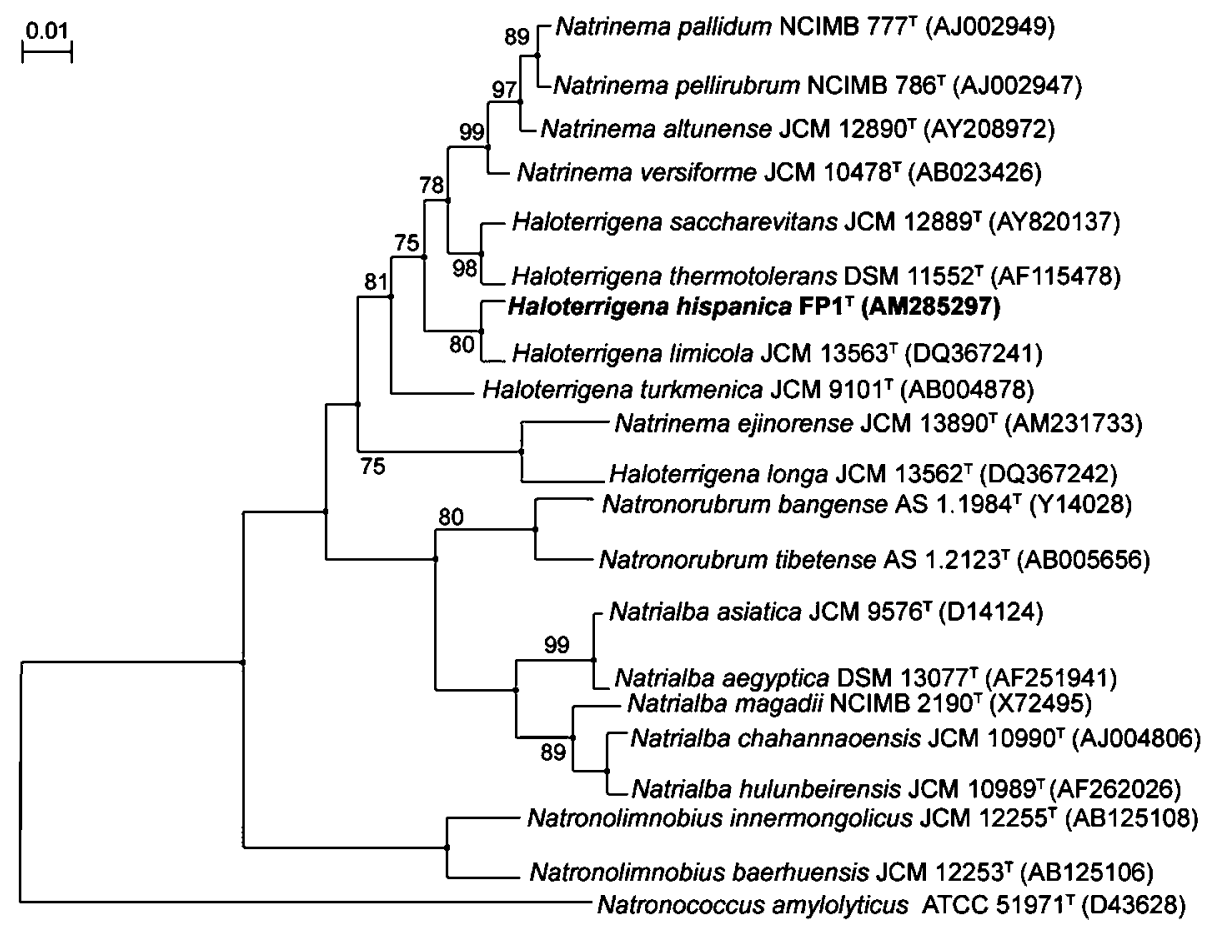

Fig. 1. Neighbour-joining phylogenetic tree, based on $16 \mathrm{~S}$ rRNA gene sequences, showing the relationship between strain $\mathrm{FP}^{\top}{ }^{\top}$ and related taxa. Bootstrap values (\%) are based on 1000 replicates and are shown at each node. Bar, 0.01 expected changes per site.

between strain $\mathrm{FP}^{\mathrm{T}}$ and Htg. limicola JCM $13563^{\mathrm{T}}$, Htg. thermotolerans DSM $11552^{\mathrm{T}}$, Htg. saccharevitans JCM $12889^{\mathrm{T}}$, Htg. turkmenica JCM $9101^{\mathrm{T}}$ and Htg. longa JCM $13562^{\mathrm{T}}$ were $98.9,96.2,95.6,95.5$ and $94.6 \%$, respectively, but the novel strain was also related to Natrinema versiforme JCM $10478^{\mathrm{T}}$ and Natrinema altunense JCM $12890^{\mathrm{T}}(96.1$ and $95.3 \%$ sequence similarity, respectively). The position of Natrinema ejinorense in this phylogenetic tree should be resolved in the near future (Fig. 1).

The polar lipid profile of strain $\mathrm{FP} 1^{\mathrm{T}}$, which comprised $\mathrm{C}_{20} \mathrm{C}_{20}$ and $\mathrm{C}_{20} \mathrm{C}_{25}$ derivatives of phosphatidylglycerol (PG), phosphatidylglycerol phosphate methyl ester (PGP-Me) and mannose-6-sulfate(1-2)-glucose glycerol diether (S-DGD), was consistent with that of species of the genus Haloterrigena but differed with regard to the glycolipid pattern. The type strains of recognized species of the genus Haloterrigena possess mannose-2,6-disulfate(1-2)-glucose glycerol diether ( $\mathrm{S}_{2}$-DGD) (Ventosa et al., 1999; Montalvo-Rodriguez et al., 2000; Xu et al., 2005a; Cui et al., 2006), whereas strain $\mathrm{FP}^{\mathrm{T}}$ lacks this component. Species of the genus Natrinema have been shown to possess unknown glycolipids and sulfated glycolipids (McGenity et al., 1998; Xin et al., 2000; Xu et al., 2005b) (see Supplementary Fig. S1 in IJSEM Online). Polar lipids were identified by ${ }^{1} \mathrm{H}$ and ${ }^{13} \mathrm{C}$ NMR spectra (see Supplementary Table S1) (De Rosa et al., 1988; Lanzotti et al., 1988, 1989). LC/MS as well as EI/MS analyses of the quinone content of strain $\mathrm{FP}^{\mathrm{T}}$ revealed the presence of two menaquinones, MK8 and $\mathrm{MK} 8\left(\mathrm{H}_{2}\right)$. Strain $\mathrm{FP}^{\mathrm{T}}$ accumulated PHB under optimal growth conditions. The above results indicated that strain $\mathrm{FP} 1^{\mathrm{T}}$ was a member of the genus Haloterrigena. However, it could be distinguished from recognized species of the genus Haloterrigena on the basis of several phenotypic characteristics (Table 1).

The DNA G $+\mathrm{C}$ content of strain $\mathrm{FP}^{\mathrm{T}}{ }^{\mathrm{T}}$ was determined to be 62.0 mol\%. DNA-DNA relatedness values for strain $\mathrm{FP} 1^{\mathrm{T}}$ with respect to Htg. thermotolerans DSM $11552^{\mathrm{T}}$, Htg. saccharevitans JCM $12889^{\mathrm{T}}$ and Htg. limicola JCM $13563^{\mathrm{T}}$ were $22.85,28.35$ and $23.40 \%$, respectively.

On the basis of the phylogenetic, genotypic and chemotaxonomic data presented here, we suggest that strain $\mathrm{FP}^{\mathrm{T}}$ should be classified as the type strain of a novel species within the genus Haloterrigena, for which the name Haloterrigena hispanica sp. nov. is proposed.

\section{Description of Haloterrigena hispanica sp. nov.}

Haloterrigena hispanica (his.pa'ni.ca. L. fem. adj. hispanica of Hispania, from where the organism was originally isolated).

Cells are Gram-negative, coccoid (1.5-2.0 $\mu \mathrm{m}$ in diameter) and become oval in stationary cultures. Colonies on complex agar medium with $3.4 \mathrm{M} \mathrm{NaCl}$ are light red, elevated and circular. Growth occurs at $\mathrm{NaCl}$ concentrations of 2.2-4.0 M, at $\mathrm{Mg}^{2+}$ concentrations of $0-0.4 \mathrm{M}$, at $\mathrm{pH}$ values in the range $6.5-8.5$ and at temperatures of $37-60{ }^{\circ} \mathrm{C}$. The 
Table 1. Characteristics that distinguish strain $\mathrm{FP}^{\top}{ }^{\top}$ from species of the genus Haloterrigena and from Natrinema altunense

Taxa: 1, strain $\mathrm{FP}^{\mathrm{T}}$; 2, Htg. saccharevitans $\mathrm{AB}^{\mathrm{T}}{ }^{\mathrm{T}}$ (data from Xu et al., 2005a); 3, Htg. thermotolerans DSM $11552^{\mathrm{T}}$ (data from MontalvoRodriguez et al., 2000); 4, Htg. turkmenica VKM B-1734 (data from Ventosa et al., 1999); 5, Htg. limicola AX-7 ${ }^{\mathrm{T}}$ (data from Cui et al., 2006); 6, Htg. longa $\mathrm{ABH}_{3}{ }^{\mathrm{T}}$ (data from Cui et al., 2006); 7, N. altunense $\mathrm{AJ} 2^{\mathrm{T}}$ (data from Xu et al., 2005b). +, Positive; -, negative; W, weak; NR, data not reported; UK, unknown; S-DGD, mannose-6-sulfate(1-2)-glucose glycerol diether; S 2 -DGD, mannose-2,6-disulfate(1-2)glucose glycerol diether.

\begin{tabular}{|c|c|c|c|c|c|c|c|}
\hline Characteristic & 1 & 2 & 3 & 4 & 5 & 6 & 7 \\
\hline Cell morphology & Coccoid & Rods/coccoid & Rods & Coccoid & Rods & Rods & Rods \\
\hline $\mathrm{NaCl}$ range $(\mathrm{M})$ & $>2.2$ & $>1.7$ & $>2.0$ & $>2.0$ & $>1.7$ & $>1.7$ & $>1.7$ \\
\hline DNA G $+C$ content $(\mathrm{mol} \%)$ & 62.0 & 66.6 & 63.3 & 59.8 & 61.9 & 63.2 & 65.6 \\
\hline Cell size $(\mu \mathrm{m})$ & $1.5-2.0$ & $0.8-7.0$ & $4-13$ & $1.5-2.0$ & $0.7-2.7$ & $\begin{array}{c}0.5-0.6 \times \\
2.8-11\end{array}$ & $1.0-5.0$ \\
\hline Lysis in distilled water & + & NR & + & - & NR & NR & + \\
\hline Temperature optimum $\left({ }^{\circ} \mathrm{C}\right)$ & 50 & $42-45$ & 50 & 45 & $40-50$ & $41-45$ & 37 \\
\hline Use of sugars as carbon source & - & - & - & + & - & + & + \\
\hline Gelatin liquefaction & - & - & $\mathrm{W}$ & - & - & - & + \\
\hline Hydrolysis of Tween 20 & - & NR & NR & NR & + & + & + \\
\hline Major glycolipid & S-DGD & $\mathrm{S}_{2}$-DGD & $\mathrm{S}_{2}-\mathrm{DGD}$ & $\mathrm{S}_{2}$-DGD & $\mathrm{S}_{2}$-DGD & $\mathrm{S}_{2}$-DGD & $\begin{array}{l}\text { One major } \\
\text { glycolipid: UK }\end{array}$ \\
\hline Sensitivity to tetracycline & - & + & - & NR & - & - & NR \\
\hline Motility & - & + & - & + & + & - & + \\
\hline
\end{tabular}

optimal $\mathrm{NaCl}$ concentration, $\mathrm{Mg}^{2+}$ concentration, $\mathrm{pH}$ and temperature for growth are $3.4 \mathrm{M}, 0.2 \mathrm{M}, \mathrm{pH} 7.0$ and $50{ }^{\circ} \mathrm{C}$, respectively. Chemo-organotrophic and aerobic. Oxidaseand catalase-positive. Indole formation is positive. Nitrate reduction is observed but nitrite reduction is not. Gelatin, starch, casein, and Tweens 20, 40 and 60 are not hydrolysed. The following substrates are utilized for growth: glycerol, sodium acetate, sodium propionate and sodium citrate. Glucose, mannose, rhamnose, fructose, sucrose, galactose, trehalose, ribose, xylose, cellobiose and arabinose are not utilized for growth. Sensitive to ( $\mu$ g per disc) fusidic acid (10), bacitracin (10) and novobiocin (30). Resistant to the following antibiotics ( $\mu$ g per disc): streptomycin (25), tetracycline (50), nystatin (100), vancomycin (30), kanamycin (30), lincomycin (10), neomycin (30), erythromycin (30), ampicillin (25), chloramphenicol (50) and penicillin (10 U). Major polar lipids are $\mathrm{C}_{20} \mathrm{C}_{20}$ and $\mathrm{C}_{20} \mathrm{C}_{25}$ derivatives of PG, PGP-Me and S-DGD. The DNA G+C content is $62.0 \mathrm{~mol} \%\left(T_{\mathrm{m}}\right)$.

The type strain, $F P 1^{\mathrm{T}}\left(=\mathrm{DSM} 18328^{\mathrm{T}}=\right.$ ATCC BAA$1310^{\mathrm{T}}$ ), was isolated from Fuente de Piedra salt lake, southern Spain.

\section{Acknowledgements}

This work was partially supported by Regione Campania. We thank Valeria Calandrelli and Eduardo Pagnotta for technical assistance and Vincenzo Mirra and Salvatore Zambardino for NMR imaging. We are grateful to Dr Manuel Rendon, Director-Curator of Fuente de Piedra Nature Reserve, for his assistance during sampling.

\section{References}

Castillo, A. M., Gutierrez, M. C., Kamekura, M., Xue, Y., Ma, Y., Cowan, D. A., Jones, B. E., Grant, W. D. \& Ventosa, A. (2006). Natrinema ejinorense sp. nov., isolated from a saline lake in Inner Mongolia, China. Int J Syst Evol Microbiol 56, 2683-2687.

Chenna, R., Sugawara, H., Koike, T., Lopez, R., Gibson, T. J., Higgins, D. G. \& Thompson, J. D. (2003). Multiple sequence alignment with the Clustal series of programs. Nucleic Acids Res 31, 3497-3500.

Cui, H. L., Tohty, D., Zhou, P. J. \& Liu, S. J. (2006). Haloterrigena longa sp. nov. and Haloterrigena limicola sp. nov., extremely halophilic archaea isolated from a salt lake. Int J Syst Evol Microbiol 56, 1837-1840.

De Rosa, M., Gambacorta, A., Grant, W. D., Lanzotti, V. \& Nicolaus, B. (1988). Polar lipids and glycine betaine from haloalkaliphilic archaeabacteria. J Gen Microbiol 134, 205-211.

Dussault, H. P. (1955). An improved technique for staining red halophilic bacteria. J Bacteriol 70, 484-485.

Ezaki, T., Hashimoto, Y. \& Yabuuchi, E. (1989). Fluorometric deoxyribonucleic acid-deoxyribonucleic acid hybridization in microdilution wells as an alternative to membrane filter hybridization in which radioisotopes are used to determine genetic relatedness among bacterial strains. Int J Syst Bacteriol 39, 224-229.

Felsenstein, J. (2004). PHYLIP (phylogeny inference package), version 3.6. Distributed by the author. Department of Genome Sciences, University of Washington, Seattle, USA.

Fendrihan, S., Legat, A., Pfaffenhuemer, M., Gruber, C., Weidler, G., Gerbl, F. \& Stan-Lotter, H. (2006). Extremely halophilic archaea and the issue of long-term microbial survival. Rev Environ Sci Biotechnol 5, 203-218.

Goris, J., Suzuki, K., De Vos, P., Nakase, T. \& Kersters, K. (1998). Evaluation of a microplate DNA-DNA hybridization method compared with the initial renaturation method. Can J Microbiol 44, 1148-1153. 
Grant, W. B. (2004). Introductory chapter: half a lifetime in Soda Lakes. In Halophilic Microorganisms, pp. 17-22. Edited by A. Ventosa. Heidelberg: Springer.

Halebian, S., Harris, B., Finegold, S. M. \& Rolfe, R. (1981). Rapid method that aids in distinguishing Gram-positive from Gramnegative anaerobic bacteria. J Clin Microbiol 13, 444-448.

Kamekura, M. \& Dyall-Smith, M. L. (1995). Taxonomy of the family Halobacteriaceae and the description of two new genera Halorubrobacterium and Natrialba. J Gen Appl Microbiol 41, 333-350.

Kumar, S., Tamura, K. \& Nei, M. (2004). MEGA3: Integrated software for molecular evolutionary genetics analysis and sequence alignment. Brief Bioinform 5, 150-163.

Lanzotti, V., Nicolaus, B., Tincone, A. \& Grant, W. D. (1988). The glycolipid of Halobacterium saccharovorum. FEMS Microbiol Lett 55, 223-228.

Lanzotti, V., Nicolaus, B., Tincone, A., De Rosa, M., Grant, W. D. \& Gambacorta, A. (1989). A complex lipid with a cyclic phosphate from the archaebacterium Natronococcus occultus. Biochim Biophys Acta 1001, 31-34.

Martinez-Canovas, M. J., Bejar, V., Martinez-Checa, F. \& Quesada, E. (2004). Halomonas anticariensis sp. nov., from Fuente de Piedra, a saline-wetland wildfowl reserve in Malaga, southern Spain. Int J Syst Evol Microbiol 54, 1329-1332.

Martinez-Checa, F., Bejar, V., Llamas, I., Del Moral, A. \& Quesada, E. (2005). Alteromonas hispanica sp. nov., a polyunsaturated-fattyacid-producing, halophilic bacterium isolated from Fuente de Piedra, southern Spain. Int J Syst Evol Microbiol 55, 2385-2390.

Mata, J. A., Bejar, V., Llamas, I., Arias, S., Bressollier, P., Tallon, R., Urdaci, M. C. \& Quesada, E. (2006). Exopolysaccharides produced by the recently described halophilic bacteria Halomonas ventosae and Halomonas anticariensis. Res Microbiol 157, 827-835.

McGenity, T. J., Gemmell, R. T. \& Grant, W. D. (1998). Proposal of a new halobacterial genus Natrinema gen. nov., with two species Natrinema pellirubrum nom. nov. and Natrinema pallidum nom. nov. Int J Syst Bacteriol 48, 1187-1196.

Montalvo-Rodriguez, R., Lopez-Garriga, J., Vreeland, R. H., Oren, A., Ventosa, A. \& Kamekura, M. (2000). Haloterrigena thermotolerans sp. nov., a halophilic archaeon from Puerto Rico. Int J Syst Evol Microbiol 50, 1065-1071.

Motta, A., Romano, I. \& Gambacorta, A. (2004). Rapid and sensitive method for osmolyte determination. J Microbiol Methods 58, 289-294.

Nicolaus, B., Manca, M. C., Lama, L., Esposito, E. \& Gambacorta, A. (2001). Lipid modulation by environmental stresses in two models of extremophiles isolated from Antarctica. Polar Biol 24, 1-8.

Oren, A. \& Galinski, E. A. (1994). Hydrolysis of $N^{\prime}$-benzoyl-argininep-nitroanilide stereoisomers as a phenotypic test: a study of Grampositive halotolerant bacteria. Syst Appl Microbiol 17, 7-10.
Oren, A., Ventosa, A. \& Grant, W. D. (1997). Proposal of minimal standards for the description of new taxa in the order Halobacteriales. Int J Syst Bacteriol 47, 233-238.

Oren, A., Elevi, R., Watanabe, S., Ihara, K. \& Corcelli, A. (2002). Halomicrobium mukohataei gen. nov., comb. nov., and emended description of Halomicrobium mukohataei. Int J Syst Evol Microbiol 52, 1831-1835.

Poli, A., Esposito, E., Lama, L., Orlando, P., Nicolaus, G., de Appolonia, F., Gambacorta, A. \& Nicolaus, B. (2006). Anoxybacillus amylolyticus sp. nov., a thermophilic amylase producing bacterium isolated from Mount Rittmann (Antarctica). Syst Appl Microbiol 29, 300-307.

Reed, A. J., Lutz, R. A. \& Vetriani, C. (2006). Vertical distribution and diversity of bacteria and archaea in sulphide and methane-rich cold seep sediments located at the base of the Florida Escarpment. Extremophiles 10, 199-211.

Romano, I., Manca, M. C., Lama, L., Nicolaus, B. \& Gambacorta, A. (1993). A method for antibiotic assay on Sulfolobales. Biotechnol Tech 7, 439-440.

Sykes, J. (1971). Methods in microbiology. In Centrifugal Techniques for the Isolation and Characterization of Sub-cellular Components from Bacteria, pp. 189-193. Edited by J. R. Norris \& D. W. Ribbons. London: Academic Press.

Tamaoka, J. \& Komagata, K. (1984). Determination of DNA base composition by reversed-phase high-performance liquid chromatography. FEMS Microbiol Lett 25, 125-128.

Tindall, B. J. (2003). Taxonomic problems arising in the genera Haloterrigena and Natrinema. Int J Syst Evol Microbiol 53, 1697-1698.

Ventosa, A., Gutiérrez, M. C., Kamekura, M. \& Dyall-Smith, M. L. (1999). Proposal to transfer Halococcus turkmenicus, Halobacterium trapanicum JCM 9743 and strain GSL-11 to Haloterrigena turkmenica gen. nov., comb. nov. Int J Syst Bacteriol 49, 131-136.

Wright, A. D. (2006). Phylogenetic relationships within the order Halobacteriales inferred from $16 \mathrm{~S}$ rRNA gene sequences. Int J Syst Evol Microbiol 56, 1223-1227.

Xin, H., Itoh, T., Zhou, P., Suzuki, K., Kamekura, M. \& Nakase, T. (2000). Natrinema versiforme sp. nov., an extremely halophilic archaeon from Aibi salt lake, Xinjiang, China. Int J Syst Evol Microbiol 50, 1297-1303.

Xu, X. W., Liu, S. J., Tohty, D., Oren, A., Wu, M. \& Zhou, P. J. (2005a). Haloterrigena saccharevitans sp. nov., an extremely halophilic archaeon from Xin-Jiang, China. Int J Syst Evol Microbiol 55, 2539-2542.

Xu, X. W., Ren, P.-G., Liu, S.-J., Wu, M. \& Zhou, P. J. (2005b). Natrinema altunense sp. nov., an extremely halophilic archaeon isolated from a salt lake in Altun Mountain in Xin-Jiang, China. Int J Syst Evol Microbiol 55, 1311-1314. 